\title{
STUDI DESKRIPTIF BENTUK PERMAINAN KEGIATAN KEPRAMUKAAN DALAM MENGEMBANGKAN SIKAP TANGGUNG JAWAB KERJASAMA DAN TOLONG MENOLONG PADA INTERAKSI SOSIAL SISWA SD NEGERI 68 KOTA BENGKULU
}

\author{
Ferian Tri Cahyo ${ }^{1)}$, Puspa Djuwita ${ }^{2)}$, Wasidi ${ }^{3)}$ \\ ${ }^{1)}$ Mahasiswa Program Studi Pendidikan Dasar, Program Pascasarjana Universitas Bengkulu \\ ${ }^{2), 3)}$ Dosen Pascasarjana Prodi Pendidikan Dasar Universitas Bengkulu \\ E-mail : Feriantricahyo0810@gmail.com
}

\begin{abstract}
Scouting game is one form of group activity that can be used as a filler of scouting activity in school that aims to develop student social interaction. The approach and type of research used is descriptive qualitative. The source of the data in this study was the coach, assistant builder and scout members of the City of Bengkulu 68 Elementary School. Data collection techniques using observation, interviews, and documentation by testing the credibility of the data through observation persistence, negative case analysis and member check. The data obtained were analyzed by data reduction, data presentation (display), and conclusion. The results of this study indicate, games that develop social interaction are group games. Conclusion, a form of game that develops social interaction, namely picture puzzle, memarkirkan kendaraan, and estafet air. The attitude of student responsibility is seen when implementing the rules of playing consistently and carrying out tasks well.The attitude of student collaboration can be seen from the business activities with students in completing the game. And the attitude of helping students is seen when students actively help each other in the process of completing the game
\end{abstract}

Keywords: scouting game, social interaction.

Abstrak

Permainan kepramukaan adalah salah satu bentuk kegiatan berkelompok yang dapat digunakan sebagai pengisi kegiatan latihan kepramukaan di sekolah yang bertujuan untuk mengembangkan interaksi sosial siswa. Pendekatan dan jenis penelitian yang digunakan adalah deskriptif kualitatif. Sumber data dalam penelitian ini adalah pembina, asisten pembina dan anggota pramuka SD Negeri 68 Kota Bengkulu. Teknik pengumpulan data menggunakan observasi, wawancara, dan dokumentasi dengan uji kredibilitas data melalui ketekunan pengamatan, analisis kasus negatif dan member check. Data yang diperoleh dianalisis melalui reduksi data, penyajian data (display), dan penarikan kesimpulan. Hasil penelitian ini menunjukkan, permainan yang mengembangkan interaksi sosial adalah permainan berkelompok. Kesimpulan, bentuk permainan yang mengembangkan interaksi sosial yaitu picture puzzle, memarkirkan kendaraan, dan estafet air. Sikap tanggung jawab siswa terlihat saat melaksanakan aturan bermain secara konsisten dan melaksanakan tugas dengan baik. Sikap kerjasama siswa terlihat dari kegiatan usaha bersama siswa dalam menyelesaikan permainan. Dan sikap tolong menolong siswa terlihat saat siswa saling aktif membantu dalam proses menyelesaikan permainan.

Kata kunci: permainan kepramukaan, interaksi sosial. 


\section{Pendahuluan}

Perkembangan pada zaman globalisasi ini, perkembangan yang terjadi hampir pada semua bidang. Salah satunya perkembangan yang sangat pesat saat ini yaitu teknolongi. Perkembangan teknologi juga berpengaruh pada dunia usia anakanak. Semakin hari semakin kreatif dan inovatif manusia dalam menciptakan berbagai macam permainan yang berbasis teknologi untuk usia anak-anak.

Banyaknya permainan dalam bentuk teknologi yang telah beredar dikalangan masyarakat luas sudah menimbulkan berbagai dampak negatif maupun positif. Dampak positif yang diperoleh oleh anak adalah, mengurangi stres anak yang seharian belajar di sekolah, karena permainan gadget dominan menggunakan bahasa inggris, anak menjadi terlatih sedikitnya bahasa inggris yang digunakan dalam permainan tersebut.

Permainan berbasis teknologi juga dapat menimbulkan beberapa dampak negatif, anak kurang akif bergerak fisik karena yang bergerak hanya jarinya saja. Selain itu juga, tidak adanya komunikasi anak dengan temannya dalam bermain permainan gadget. Hal tersebut sangat disayangkan, usia anak-anak seharusnya lebih bersosialisasi dengan teman sebayanya dan bergerak aktif.

Seharusnya dunia usia anak-anak lebih dominan untuk berlatih bersosialisasi dengan teman sebayanya dengan kegiatan bertatap muka supaya terbentuk saling berkomunikasi dan memecahkan masalah secara bersama-sama serta melakukan sesuatu yang membuat anak saling memahami dan menghargai antara satu sama lain sehingga menimbulkan rasa saling membutuhkan. kebutuhan anak yang wajib terpenuhi untuk menghadapi perubahan zaman yang akan terjadi kedepan, adalah membentuk interaksi sosial dalam diri anak. Hal tersebut bermanfaat untuk anak, supaya anak dapat lebih sering berkemounikasi terhadap temannya sehingga dapat mengembangkan emosional anak.

Fenomena yang terjadi akhir-akhir ini, permainan digital berdampak buruk pada anak. Di berbagai media baik cetak maupun elektronik saat ini, marak diberitakan tentang berbagai dampak permainan digital pada anak, khususnya game online. Anak yang bermain game online tanpa adanya kontrol, khususnya dari orang tua, cenderung mengalami kecanduan. Akibatnya, sebagian besar waktu anak digunakan untuk bermain game online. Permasalahan umum yang terjadi dengan permasalahan game digital saat ini, Nur (2013 : 88) anak-anak menghabiskan waktunya berjam- jam bermain game tanpa peduli dengan lingkungannya, materi games bermuatan kekerasan yang berpadu dengan pornografi 
lebih banyak diminati oleh anak-anak, di Surakarta ada tujuh anak yang melakukan pencurian demi bisa bermain game online.

Dari permasalahan tersebut, untuk menumbuhkan dan mengembangkan interaksi sosial anak dapat dilakukan melalui kegiatan kepramukaan. Menurut Khamadi (2015 : 57) pramuka merupakan wadah di mana tempat seorang anak menempa watak dan kepribadian yang ada di dalam dirinya sebelum ia mengahadapi dunia nyata dalam kehidupan bermasyarakat, berbangsa dan bernegara. Pramuka adalah pendidikan non formal yang dilakukan diluar sekolah, keluarga untuk membentuk dan mengembangkan sikap interaksi sosial siswa terhadap sesamanya. Karena kepramukaan dilakukan dengan metode berkelompok sehingga siswa dapat saling berinteraksi terhadap sesama temannya dalam satu kelompok maupun diluar kelompok.

Pada sekolah dasar pendidikan kepramukaan sebagai wadah membangun karakter siswa yang dapat dilakukan lebih banyak bermain daripada teorinya. Menurut Triharso (2013: 10) Bermain memberikan banyak manfaat yang dapat menunjang perkembangan anak. Oleh karena itu permainan dalam kegiatan kepramukaan tingkat siaga sebagai kegiatan latihan untuk mengembangkan antara lain, kepemimpinan, kerja sama, berdemokrasi dan interaksi sosial pada siswa.

Permainan dalam kepramukaan adalah permainan yang dapat membuat siswa senang untuk mengikutinya. Permainan kepramukaan yang dimaksud adalah permainan yang dilakukan secara berkelompok. Permainan - permainan kepramukaan dalam mengembangkan interaksi sosial siswa di desain dengan baik sedemikian rupa supaya cocok digunakan untuk mengembangkan interaksi siswa bersama temannya. Salah satu permainan yang dilakukan dalam kegiatan kepramukaan secara berkelompok yaitu bom activity satu, mutiara dua, estafet bendera, terompa, dll.

Berdasarkan observasi awal yang dilakukan di SD Negeri 68 Kota Bengkulu, siswa masih tampak kurang peduli antar sesama temannya ini dilihat ketika ada temannya yang sedang terjatuh kemudian ditertawakan oleh temannya, masih terdapat siswa yang membentuk kelompok tertentu dan tidak mau bergaul dengan teman-teman yang lain, siswa masih memilih-milih teman yang ingin dijadikan teman kelompoknya ketika diarahkan oleh pembina.

Berdasarkan penemuan tersebut, peneliti ingin mengangkat permasalahan yaitu 1) bagaimana bentuk permainan yang dapat mengembangkan interaksi sosial siswa? 2) bagaimana proses permainan 
kepramukaan dalam mengembangkan sikap tanggung jawab pada interaksi sosial siswa?

\section{Metode Penelitian}

Pendekatan dalam penelitian ini menggunakan pendekatan kualitatif, yaitu metode penelitian yang tidak menguji hipotesis, tetapi hanya akan mendeskripsikan informasi sesuai kejadian dengan variabel-variabel yang ditentukan dan diteliti. Seperti yang diungkapkan oleh Sukmadinata (2007: 60) penelitian kualitatif (qualitative research) adalah suatu penelitian yang ditujukan untuk mendeskripsikan dan menganalisis fenomena, peristiwa, aktivitas sosial, sikap, kepercayaan, persepsi, pemikiran orang secara individu maupun kelompok.

Teknik sampling yang digunakan dalam penelitian kualitatif ini adalah snowball sampling. Menurut Sugiyono (2007: 54) snowball sampling adalah teknik pengambilan sampel sumber data, yang pada awalnya jumlahnya sedikit, lama-lama menjadi besar. Teknik dapat digunakan untuk mengumpulkan data dari berbagai sumber sebanyak mungkin untuk melengkapi data yang diperlukan dalam peneitian ini.

Dalam penelitian ini menurut Sukmadinata (2007: 285) memilih informan expert yang menjadi sumber data ditentukan dan informan ini diurut berdasarkan pengaruhnya dalam kegiatan yang diteliti. Orang yang menguasai informasi tentang kepramukaan di SD Negeri 68 Kota Bengkulu yaitu pembina pramuka oleh bapak SY dan assisten pembina pramuka oleh IS. Data yang diperoleh dari Informan expert tersebut adalah data yang dijadikan oleh peneliti sebagai sumber data yang real dan benar benar terjadi.

Data yang telah diobservasi adalah data siswa yang menjadi anggota pramuka yang aktif dalam kegiatan ekstrakurikuler pramuka di SDN Negeri 68 Kota Bengkulu. Jumlah siswa yang menjadi anggota aktif adalah berjumlah dua puluh lima siswa dengan rincian putra sebanyak enam orang dan putri sebanyak sembilan belas orang .

Jenis penelitian kualitatif, peneliti adalah sebagai intsrumen atau alat dalam penelitian itu sendiri. Menurut Sugiyono (2007: 59) Peneliti kualitatif sebagai human instrument, berfungsi menetapkan fokus penelitian, memilih informan sebagai sumber data, melakukan pengumpulan data, menganalisis data, dan membuat kesimpulan.

Uraian yang dijelaskan di atas menjelaskan bahwa instrumen dalam penelitian adalah suatu alat yang digunakan untuk mengukur suatu fenomena yang terjadi dan diamati. Pada penelitian ini instrumen yang digunakan 
adalah pedoman observasi dan pedoman wawancara.

Teknik pengumpulan data yang digunakan dalam penelitian ini adalah observasi, wawancara, dan dokumentasi.

Pengumpulan dan analisis data penelitian kualitatif bersifat interaktif, berlangsung dalam lingkaran yang tumpah tindih. Langkah-langkah disebut strategi pengumpulan dan analisis data, teknik yang digunakan dan data yang telah diperoleh (Sukmadinata, 2007: 114)

Aktivitas analisis data dalam penelitian ini, menurut Sugiyono (2007: 91) yaitu data reduction, data display, dan conclusion drawing/verification.

Pada dasarnya dalam penelitian deskripsi belum ada teknik yang baku dalam menganalisa data, oleh sebab itu ketajaman dan kelihaian peneliti dalam melihat data serta kekayaan pengalaman dan pengetahuan harus dimiliki oleh peneliti. Dalam menguji keabsahan data penelitian ini peneliti harus melakukan uji kredibilitas data supaya data yang diperoleh dan disimpulkan adalah data yang sah dan diterima oleh pihak-pihak yang berperan dalam penelitian ini.

Uji kredibilitas data atau kepercayaan terhadap data hasil penelitian ini antara lain dilakukan dengan peningkatan ketekunan dalam pengamatan, analisis kasus negatif, dan member check.
Hasil Dan Pembahasan

1. Hasil Penelitian

a. Kegiatan-Kegiatan Kepramukaan Yang Dilakukan Di SD Negeri 68 Kota Bengkulu.

Berbagai macam kegiatan ekstrakurikuler yang dilaksanakan di sana, salah satunya adalah pramuka. Kegiatan kepramukaan yang dilakukan berbagai macam, semua bertujuan untuk melatih keberanian, tanggung jawab, tolong menolong, kepemimpinan, kerjasama, kekompakan, dan kreativitas siswa supaya menjadi orang yang memiliki kepribadian. Kegiatan-kegiatan tersebut meliputi 1) tata upacara siaga (TUS), 2) kreatifitas yel-yel yaitu siswa membuat yel-yel secara berkelompok, 3) latihan baris-berbaris, 4) bernyanyi, 5) tali-temali, 6) permainan, 7) hiking mini/jalan santai, 8) kebersihan jalan.

Jadwal latihan rutin di SD Negeri 68 Kota Bengkulu dilakukan dua kali dalam satu Minggu, setiap hari Kamis dan hari Sabtu waktu latihan perminggunya dilakukan selama dua jam. Jadwal hari Sabtu dilakukan oleh seluruh kelas dengan menggunakan sistem blok pada jam 7.30 sampai jam 08.30 WIB. Jadwal hari Kamis dilakukan pada jam 15.00 sampai 17.00 WIB dilakukan oleh siswa yang ingin mengikuti pramuka sistem reguler atau biasa dikatakan kegiatan ekstrakurikuler pramuka. Siswa mengikuti kegiatan pramuka dengan bergembira dan 
bersemangat, merekapun menunggununggu datangnya hari Kamis dan Sabtu untuk mengikuti kegiatan pramuka.

\section{b. Bentuk Permainan Kepramukaan dalam Mengembangkan Interaksi Sosial Sebagai Pengisi Kegiatan Latihan Pramuka}

Mendengar kata permainan pasti itu hal yang menyenangkan. Dunia anak adalah dunia permainan dan dari permainan itulah anak dapat mengembangkan potensi dirinya. Bermacam-macam jenis permainan yang ada di dunia ini dan dapat dilakukan oleh siapapun, permainan dilakukan supaya siswa menjadi senang, rajin datang dalam mengikuti latihan pramuka.

Permainan-permainan yang dilakukan dalam kepramukaan di SD Negeri 68 Kota Bengkulu bermacammacam yang meliputi permainan individu maupun kelompok. Permainan individu seperti 1) kepiting berjalan, 2) bos berkata. Permainan kelompok seperti 1) pesta kembang api, 2) kipas sate, 3) memakirkan kendaraan, 4) picture puzzle, 5) estafet Air, 6) harta karun, 7) estafet kertas, 8) estafet lagu, 9) mutiara dua.

Sebelum memulai kegiatan, anggota pramuka dan pembina melaksanakan kegiatan rutin yaitu melaksanakan upacara pembukaan latihan siaga. Upacara ini sebagai pemanasan dan menyiapkan siswa untuk melaksanakan kegiatan latihan.
Setelah upacara dilaksanakan siswa bernyanyi dengan dipandu oleh pembinanya, bernyanyi lagu kepramukaan atau yel-yel kreasi yang telah diajarkan maupun dibuat oleh siswa itu sendiri. Kemudian pembina memberikan ice breaking kepada siswa yaitu kegiatan pemanasan seperti latihan konsentrasi menggunakan tepuk - tepukan supaya siswa menjadi lebih semangat dalam mempelajari materi yang akan dipelajari pada pertemuan tersebut.

\section{c. Hasil observasi permainan picture puzzle dalam mengembangkan interaksi sosial siswa}

$\begin{array}{rrr}\text { Permainan } & \text { Picture } & \text { Puzzle } \\ \text { merupakan } & \text { permainan } & \text { yang }\end{array}$
mengutamakan kerjasama, tanggung jawab dan saling menolong antar individu dalam sebuah kelompok. Permainan ini menggambarkan mencari potonganpotongan gambar yang masih berantakan, gambar potongannya adalah gambar doraemon dan kawan kawan, tugas siswa adalah menyusun kembali potongan gambar sehingga menjadi gambar yang benar. Permainan picture puzzle ini memiliki aturan bermain yaitu sebagai berikut: 1) siswa menyiapkan gambar di tempat yang telah ditentukan, 2) siswa menyusun potongan gambar secara bersama, 3) waktu yang diberikan dalam bermain yaitu 10 menit, 4) tim yang selesai 
terlebih dahulu menyusun gambar menjadi pemenang.

Berdasarkan pengamatan yang dilakukan di SD Negeri 68 Kota Bengkulu pada hari Selasa tanggal 17 April 2018 tentang permainan picture puzzle. Permainan dilakukan oleh siswa sebanyak 25 siswa atau lima barung dalam satu barung berjumlah lima siswa (nama-nama siswa pada lampiran dilampirkan). Satu barung putra dan empat barung putri. Permainan ini dilakukan dengan sistem perlombaan yaitu satu lawan satu.

Permainan ini dilakukan dengan cara siswa diberikan potongan puzzle di dalam kotak kemudian siswa meletakkan di tempat yang ditentukan. Siswa bersiap di garis start, setelah siap siswa diberikan aba-aba oleh pembina pertanda siswa memulai mencari dan menyusun potongan puzzle menjadi suatu gambar yang utuh bersama teman sekelompoknya, dan kelompok yang selesai terlebih dahulu menjadi pemenang.

Salah satu kelompok yang bermain permainan ini adalah barung kuning. Barung kuning adalah barung yang beranggotakan lima orang putri kelas lima. Barung ini diketuai oleh FL. Barung kuning sudah menyiapkan alat yang akan dimainkan sebelum permainan dimulai, kemudian melakukan diskusi berbagi tugas sebelum bermain dan segera bersiap di garis start. Ketika aba-aba terdengar dari pembina, mereka segera berlari menuju kotak yang berisikan potongan gambar, kelompok ini melakukan permainan dengan menggunakan waktu yang telah disediakan dan menyelesaikan permainan ini dalam waktu tujuh menit.

Pada saat melakukan permainan, setiap anggota melakukan tugas yang telah dibagikan, FL sebagai ketua mengomandoi teman-teman berbagi tugas, untuk tugas yang menyelesaikan gmbar doremon adalah ML dan EL, FL mencari dan merapikan potongan yang ditemukan, WW dan $\mathrm{SH}$ bertugas untuk menyusun gambar nobita.

Pada saat permainan berlangsung mereka terlihat tidak membedakan atau membandingkan teman kelompoknya, mereka terlihat kompak dan saling berinteraksi. FL berkata "AI Nyusun gambar yang ini ya". WW menemukan potongan selanjutnya "nah gmbar yang ini disini dak EL, iya WW". Terlihat mereka tidak bekerja sendiri sendiri, saling berusaha dan membantu dengan serius dan penuh semangat.

Bantu membantu menyusun dan merapikan tanpa rasa egois dan saling menyemangati FL "Ayo kawan kawan cepat cepat jangan sampai kalah". Tak ada satupun yang menyalahkan temannya apabila terjadi kesalahan, FL menegur jika temannya ada melakukan kesalahan. Setiap anggota tidak menunjukan rasa 
sombong terhadap teman-temannya serta mereka senang melakukan permainan ini dengan tidak berat hati.

\section{Pembahasan}

\section{a. Bentuk Permainan Dalam Mengembangkan Interaksi Sosial Siswa}

Permainan yang dilakukan dalam penelitian ini adalah permainan yang merujuk dari teori Khamadi (2015 : 58) yaitu permainan bukan berarti main-main (tidak beraturan) tetapi dalam rangka untuk membina dan mengembangkan sikap dan ketrampilan. Permainan disusun dan diatur menyesuaikan usia siswa supaya permainan tersebut mudah dilakukan, sehingga siswa akan tertanam dan berkembang sikap-sikap baik yang terkandung di dalam permainan tersebut.

Permainan yang di lakukan adalah permainan kelompok. Menurut Harahap (2003 : 1) permainan kelompok adalah permainan yang dilakukan secara bersama dan tidak bersifat individual. Dalam permainan tersebut siswa menunjukkan perkembangan dalam berinteraksi sosial meliputi tanggung jawab atas tugasnya, kerjasama menyelesaikan tugas bersama, dan saling tolong menolong dalam menyelesaikan tugas.

Permainan tersebut sesuai dengan pendapat Mahardika (2014 : 262 ) permainan mengandung beberapa nilainilai antara lain rasa senang, adanya rasa bebas, rasa berteman, rasa demokrasi, penuh tanggung jawab, rasa patuh, rasa saling membantu. Kemudian Kurniati dalam Nur (2013 : 89) permainan dapat mestimulasi anak dalam mengembangkan kerjasama, membantu anak menyesuaikan diri, saling berinteraksi secara positif, dapat mengkondisikan anak dalam mengontrol diri, mengembangkan sikap empati terhadap teman, menaati aturan, serta menghargai orang lain.

Dalam rangka mengembangkan interaksi sosial siswa, permainan yang cocok adalah permainan kelompok. Siswa bermain bukan untuk dirinya sendiri, tetapi siswa melakukan permainan tersebut demi nama kelompoknya. Dari pemaknaan itu permainan yang dilakukan dalam penelitian ini (picture puzzle, memarkir kendaraan, estafet air) sesuai untuk mengembangkan interaksi sosial siswa. Karena pada dasarnya permainan yang dilakukan berkelompok, siswa akan saling bertatap muka, berinteraksi dan berkomunikasi. Sehingga dengan adanya kegiatan tersebut siswa akan mengalami perkembangan dalam segi interaksi sosialnya terhadap sesama temanya di dalam kelompok.

b. Permainan picture puzzle dalam mengembangkan sikap tanggun jawab pada interaksi sosial siswa

Permainan picture puzzle memiliki cara bermain yaitu adalah sebagai berikut: 
1) siswa menyiapkan gambar di tempat yang telah ditentukan, 2) siswa menyusun potongan gambar secara bersama, 3) waktu yang diberikan dalam bermain yaitu sepuluh menit, 4) tim yang selesai terlebih dahulu menyusun gambar menjadi pemenang.

Permainan picture puzzle dalam mengembangkan interaksi sosial siswa dilihat dari indikator yang telah ditetapkan. Indikator pertama siswa mampu menggunakan waktu secara efektif memilki deskriptor siswa menyelesaikan permainan dengan waktu yang telah ditetapkan dan siswa tidak membuang waktu yang telah diberikan, kedua deskriptor ini muncul pada cara bermain ketiga yaitu waktu yang diberikan dalam bermain yaitu sepuluh menit, dalam pelaksanaanya siswa telah menyelesaikan permainan dengan tidak lebih dari sepuluh menit.

Indikator kedua siswa mampu
melaksanakan tugas individu yang
diterima memiliki deskriptor, siswa
melakukan tugas yang telah dibagikan dan
siswa tidak menunjukkan sikap tidak
perduli dengan tugasnya kedua deskriptor
ini muncul pada saat cara bermain satu dan
dua yaitu pertama siswa menyiapkan
potongan gambar dan meletakkan
ketempat yang ditentukan setelah itu
mereka segera bersiap di garis start
menunggu aba-aba dari pembina, setelah

permainan dimulai terlihat mereka saling berdiskusi dan bekerjasama menyusun potongan gambar.

Indikator ketiga siswa mampu melakukan persiapan sebelum melaksanakan tugas memiliki deskriptor siswa melakukan diskusi sebelum permainan dimulai dengan serius dan siswa menunjukkan telah mempersiapkan alat permainan yang akan dilakukan. Kedua deskiptor ini muncul pada cara bermain satu. Mereka menyiapkan gambar dan mengatur strategi seperti setelah sampai ditempat potongan gambar langsung diserakkan potongannya kemudian ada yang membalikkan gambar, ada yang menyusun gambar di sebelah kanan, ada yang di sebelah kiri dan ada yang merapikan gambar setelah disusun.

Permainan kepramukaan berkelompok mengembangkan interaksi sosial siswa. Menurut Bonner dalam Santosa (2004 : 11) interaksi sosial adalah suatu hubungan antara dua atau lebih individu manusia ketika kelakuan individu yang satu mempengaruhi, mengubah, atau memperbaiki kelakuan individu yang lain atau sebaliknya. Perkembangan interaksi sosial siswa di lihat dari beberapa komponen menurut Helms \& Turnner 
dalam Andarbeni (2013 : 286) mengungkapkan bahwa pola perilaku sosial anak dapat dilihat dari anak dapat bekerjasama (cooperating) dengan teman, anak mampu membatu (helping others) orang lain, serta anak mampu melakukan tanggung jawabnya

Sesuai dengan penjelasan tanggung jawab oleh Kurniasih (2017 : 157) merupakan suatu sikap dan perilaku seorang individu untuk melaksanakan tugas dan kewajiban yang harus ia lakukan, baik tugas terhadap Tuhan YME, negara, lingkungan dan masyarakat serta dirinya sendiri. Siswa melakukan permainan dengan penuh tanggung jawab seperti, melakukan tugas yang telah dibagikan, melakukan tugas dengan tepat waktu dan melakukan tugasnya dengan serius.

\section{Kesimpulan}

Berdasarkan hasil penelitian dan pembahasan tentang bentuk permainan kegiatan kepramukaan dalam mengembangkan sikap tanggung jawab, kerjasama dan tolong menolong pada interaksi sosial siswa SD Negeri 68 Kota
Bengkulu, disimpulkan meliputi berikut ini

1. Permainan picture puzzle menonjolkan perkembangan sikap tolong menolong pada interaksi sosial siswa. Perkembangan interaksi sosial siswa terjadi pada proses kegiatan berinteraksi kepada sesama temannya dalam permainan yang berbentuk berkelompok.

2. Proses pengembangan sikap tanggung jawab siswa, didapat pada saat siswa melaksanakan aturan bermain secara konsisten, melaksanakan tugas dengan baik dan menyelesaikan permainan dengan bersama-sama.

\section{DAFTAR PUSTAKA}

Andarbeni, Sari Lisdian, 2013, Studi Tentang Kemampuan Interaksi Sosial Anak Kelompok A Dalam Kegiatan Metode Proyek Di Tk Plus Al-Falah Pungging Mojokerto, Jurnal Bk Unesa, Volume 04 Nomor 01, Hal 285-292.

Harahap, Rivai, 2003, Petunjuk Praktis Acara Latihan Mingguan Perindukan Siaga, Jakarta: Kwartir Nasional Gerakan Pramuka. 
Khamadi, 2015, Penanaman Pendidikan Karakter Pramuka Kepada Remaja Dalam Kajian Komunikasi Visual, Jurnal Desain Komunikasi Visual \& Multimedia, Volume 01 Nomor 01, Hal 55-70.

Kurniasih, Imas dan Sani, Berlin. 2017. ImplementasiKurikulum 2013: Konsep Dan Penerapan. Surabaya: Kata Pena

Mahardika, Esti Kurniawati, 2014, Peningkatan Perilaku Sosial Anak Melalui Permainan Tardisional Jawa, Jurnal Pendidikan Usia Dini, Volume 8 Edisi 2, Hal 257-268

Nur, Haerani, 2013, Membangun Karakter Anak Melalui Permainan Anak Tradisional, Jurnal Pendidikan Karakter, Volume 03 Nomor 01, Hal 87-94.

Santosa, Slamet. 2006. Dinamika Kelompok. Jakarta: PT Bumi Aksara

Sugiyono, 2007, Memahami Penelitian Kualitatif, Bandung: Alfabeta.

Sukmadinata, Nana Syaodih, 2007, Metode Penelitian Pendidikan, Bandung: PT Remaja Rosdakarya.

Triharso, Agung, 2013, Permainan kreatif dan edukatif untuk anak usia dini, Yogyakarta: Andi. 